\author{
Research Article
}

\title{
EFFECT OF YASHTIMADHU GHRITA GUDAPURANA ON POST OPERATIVE PAIN MANAGEMENT IN PATIENTS OF HAEMORRHOIDS AND FISSURE-IN-ANO WITH SPECIAL REFERENCE TO SHASTRANIPATAJA VEDANA: A RANDOMIZED CONTROLLED TRIAL
}

\section{Yogesh Badwe ${ }^{*}$, Sanjay Bhise ${ }^{2}$, Jyoti Shinde ${ }^{3}$}

*1Professor and HOD, 2PG Scholar, ${ }^{3}$ Professor, Department of Shalyatantra, Shri Ayurved Mahavidyalaya, Nagpur, Maharashtra India.

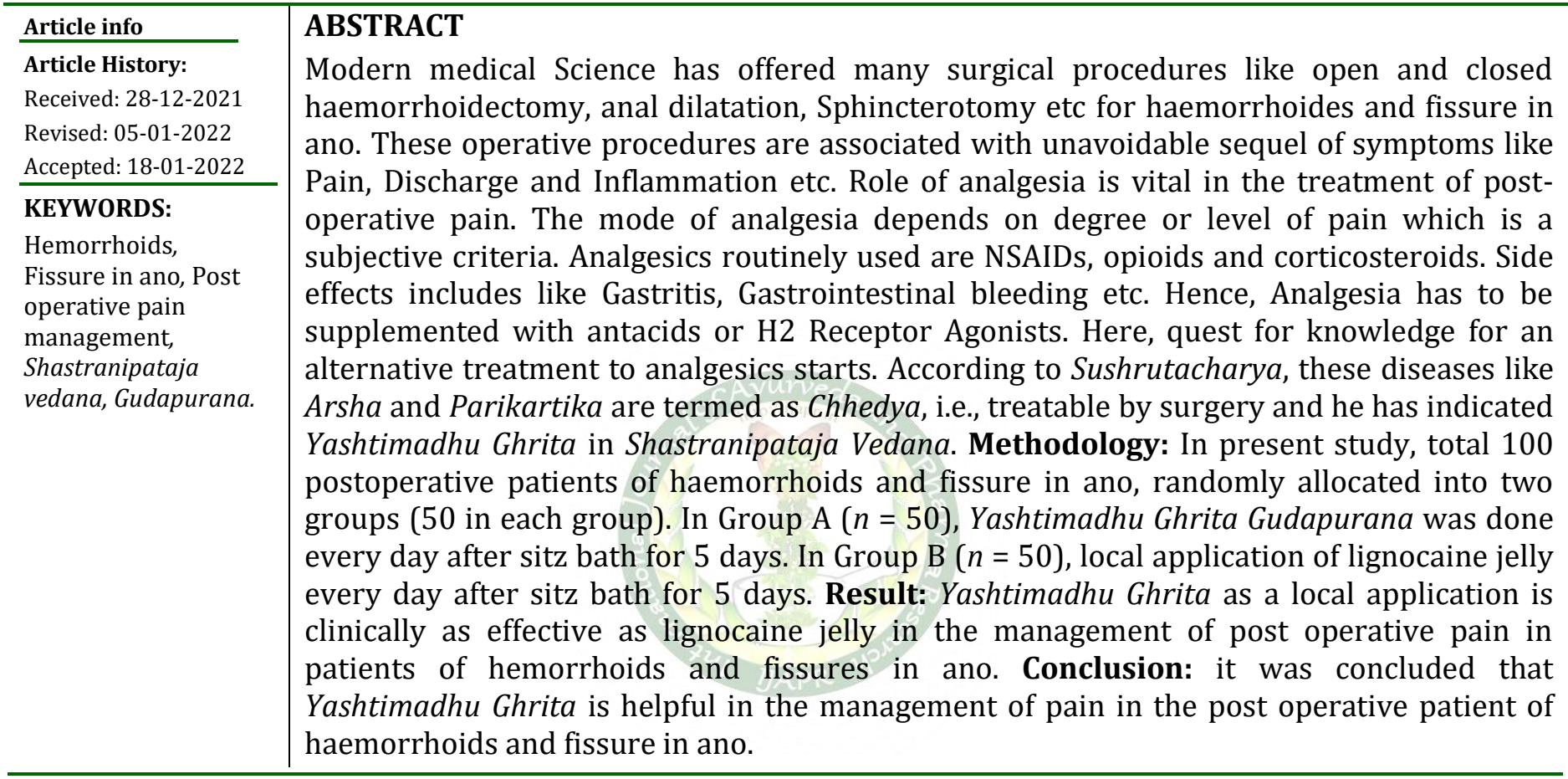

\section{INTRODUCTION}

Today "Ageless health through timeless drug therapies in alternative medicine" is the natural step forward as a choice of healthy lifestyle in our society. Pain can be described as any physical or mental suffering or discomfort caused by illness or injury. No matter however mild the pain is anywhere in the body it enables the person to land in state of discomfort and affects day to day activities. Pain can be present in various ways as throbbing pain in toothache, colic pain which comes in spasm as in renal calculi, muscular pain as in sprain, sport injury

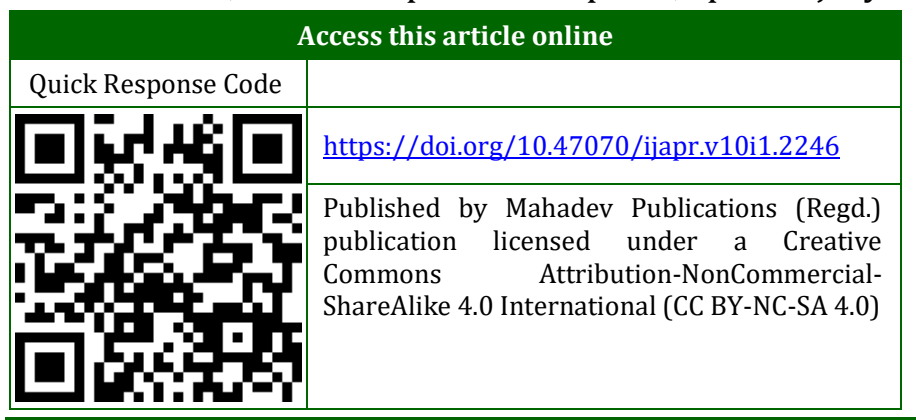

and joint pain due to inflammatory condition and many more. Pain is also categorized as acute or chronic on the basis of duration. Our answer to pain is painkiller which on frequent use kills the resistance. Similar is the case with postoperative pain. Hemorrhoids disease is the leading outpatient gastrointestinal diagnosis corresponding to $4.4 \%$ of the population seeking treatment under report incidence from age 45 to 65 years ${ }^{[1]}$. Anal fissures are most commonly seen in the posterior midline, although $10-20 \%$ in women and $1-10 \%$ in men are located in the anterior midline[2]. Haemorrhoids can be correlated to Arsha and Fissure in ano to Parikartika from the signs and symptoms. Acharya Sushruta has stated that Arsha and Parikartika are Chhedya Vyadhi. Modern medical science has offered many surgical procedures like open and closed hemorrhoidectomy, anal dilatation, sphincterotomy etc for these diseases. These operative procedures are associated with unavoidable sequel of symptoms 
like pain, discharge, and inflammation etc ${ }^{[3]}$. After Haemorrhoids surgery, pain is reported in the early post-operative period but also after 2-3days, around the time of first defecation. The aetiology of pain is believed to be multi-factorial; some important factors are individual pain thresholds, anaesthetic and analgesic protocols, operative technique, anal sphincter spasm, postoperative inflammation and secondary infections. When two groups were compared for postoperative pain management in surgeries of fissure in ano i.e., lateral anal sphincterectomy and manual anal dilatation. 45\% patients complained of persistent pain from all patients. Out of these, $60 \%$ belongs to lateral anal sphincterectomy and $40 \%$ belongs to manual anal dilatation ${ }^{4]}$. From these references it can be concluded that pain occupies the first and foremost position in post-operative symptomatology of patients. Role of analgesia is vital in the treatment of post-operative pain management. The mode of analgesia depends on degree or level of pain. In routine surgical practice, it is observed that the patient requires topical anaesthetic application for mild to moderate pain and systemic analgesic for severe degree of pain. Analgesics routinely used are NSAIDs, opioids and corticosteroids sometimes. This action is for specific short period of time and need to be taken twice or maximum thrice a day through oral or parenteral route for first 24 to 48 hours of surgery and later as per requirement, still twice daily for minimum 5 days. This increases the cost of surgical protocol by manifold. And side effects include various GI disturbances like Gastritis, GI bleeding etc. Hence, analgesia has to be supplemented with antacids or H2 Receptor Agonists.

\section{Need of Study}

Here, quest for knowledge for an alternative treatment to analgesics starts. Here Ayurveda offers a ray of hope in the form of a treatment option mentioned by Acharya Sushruta. According to him, these diseases like Arsha and Parikartika are termed as Chhedya, i.e., treatable by surgery and he has indicated Yashtimadhu Ghrita in Shastranipataja Vedana. Hence the modified release of trial drug at this level can be achieved by installation of medicated ghee with glycyrrhiza glabra (Yashtimadhu Ghrita) through anus which can be referred to as "Gudapurana" in "Shastra Nipataja Vedana "in surgical wounds of Arsha and parikartika[5]. Ghee boiled with Yashtimadhu Ghrita and applied on wound[6]. The abundant knowledge in the Ayurveda texts needs validation in the form of clinical trials and evaluation on scientific parameters. Hence, with the purpose of validation of Yashtimadhu Ghrita instillation through anus as "Gudapurana", and considering all the conceptual and practical aspects of most prevalent ano-rectal disorders, post- operative pain stigma, limitations and drawbacks of mandatory analgesic use, this study was selected.

\section{MATERIALS AND METHODS}

\section{Inclusion Criteria}

1. Post-operative patients of Haemorrhoids and fissure in ano.

2. Patient above 18 year of age, irrespective of gender and socio economic status.

\section{Exclusion Criteria}

1. Anorectal surgeries for diseases other than Haemorrhoids and Fissure in ano.

2. Patients with immuno-compromised diseases.

\section{Assessment}

\section{Subjective Criteria}

Table 1. Pain

\begin{tabular}{|c|l|}
\hline Scale reading & Pain level \\
\hline 0 & No pain \\
\hline I & Mild Pain (Annoying interfering in daily activities) which last for 1 hour after defecation \\
\hline II & Moderate pain (Interferes significantly with regular activities) which last for 1 to $3 \mathrm{hrs}$. \\
\hline III & Severe pain (Unable to perform daily activities) More Than $3 \mathrm{hrs.}$ \\
\hline
\end{tabular}

\section{Objective Criteria}

Table 2. Anal Sphinctor Muscle spasm

\begin{tabular}{|c|l|}
\hline Grade & Symptoms \\
\hline 0 & Normal (1 finger can pass) \\
\hline I & Finger can be pass with severe pain \\
\hline II & No finger can be passed \\
\hline
\end{tabular}

Overall Assessment Criteria: Criteria of assessment was based on improvement in subjective and objective parameters after the treatment. The results were categorized as,

Complete relief -- 75\% and above 
Moderate relief -- $50 \%$ to $74 \%$ improvement

Mild relief -- 25 to $49 \%$ improvement

No relief -- Below 24\% improvement

\section{Selection of Patients}

Post-operative Patients of Parikartika (fissure in ano) and Arsha (hemorrhoids) was selected from OPD or IPD of Shalya Tantra department, Shri Ayurved Mahavidyalaya, Nagpur. Irrespective of gender, occupation, religion etc., the registered patients were randomly allocated into two groups.

The study was approved by Institutional Ethics committee (IEC), before starting the clinical trial.: Institutional Ethics Committee clearance- MUHS/E- 3//PG/31/08/2350 dated 27/10/2017

Clinical study was also registered in Clinical trial register of India.

Trial register of India registration number: CTRI/2020/03/024243

\section{MATERIALS}

Among 100 registered patient in group A ( $\mathrm{n}=50)$, postoperative patients of Arsha and Parikartika were treated with Yashtimadhu Ghrita, and in group B ( $\mathrm{n}=50)$, patients of Arsha and Parikartika were treated with local application of lignocaine jelly.

\section{Methodology}

- Group A: Local application of Yashtimadhu Ghrita was done in post-operative patients of Arsha and Parikartika every day after sitz bath for 5 days.

- Group B: Local application of lignocaine jelly was done in Post-operative patients of Arsha and Parikartika every day after sitz bath for 5 days.

\section{Group A}

\section{Trial Drug}

Trial drug i.e., Yashtimadhu Ghrita was prepared and analysed on parameters like morphological evaluation, rancidity, weight $/ \mathrm{ml}$, refractive index at $25^{\circ} \mathrm{C}$, viscosity, iodine value, saponification value, acid value, peroxide value, free fatty matter and total fatty acids in the pharmacy of Shri Ayurved Mahavidyalaya, Nagpur ${ }^{[7]}$.

\section{Standard Operating Procedure (Validated)}

Under all aseptic precautions and patient in lithotomy position, painting and draping was done.

1. With gloved hand and with proper lubrication $15 \mathrm{ml}$ of Yashtimadhu Ghrita was instilled into anal canal with help of $20 \mathrm{ml}$ disposable syringe and sterile rubber catheter no. 9

2. After instillation of Yashtimadhu Ghrita Pain was assessed with VAS (visual analogue scale) scale after every 2 hours for next 8 hours.

3. Requirement of analgesics was noted and action was taken likewise.
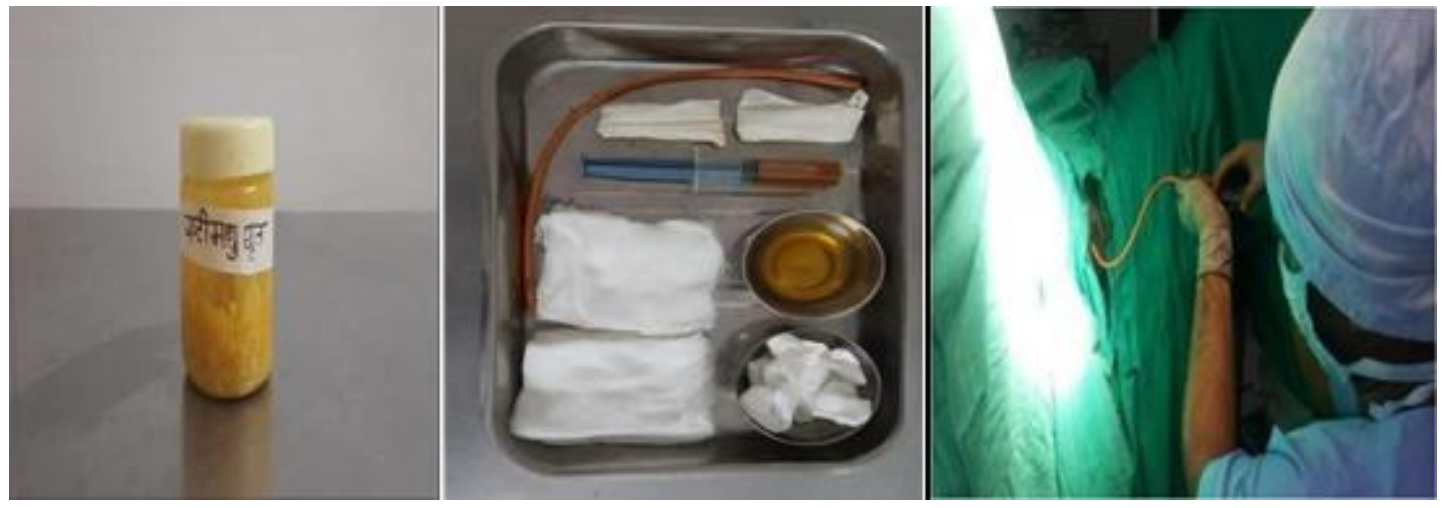

Pics no 1, 2, 3 revealing Yashtimadhu Ghrita prepared, dressing tray (instruments and procurements) and procedure of Gudapurana respectively.

\section{Group B}

Lignocaine Jelly

Application of lignocaine jelly

1. Lignocaine $2 \%$ jelly will be taken on applicator.

2. Informed patient about procedure and tell to take deep breath.

3. It will be applied per rectally with help of applicator. 
Duration of treatment: 5 Days

Follow up period: $0^{\text {th }}, 1^{\text {st }}, 2^{\text {nd }}, 3^{\text {rd }}, 4^{\text {th }}, 5^{\text {th }}$ day

\section{Statistical Tests}

Two independent samples are there, hence t test will be used and chi square test was used to access the significance of the proportion between the two groups. Within the group

Comparison: Before and after treatment was done by paired t test in each group separately. P value $<0.05$ was considered statistically significant for all comparisons Formula: for sample size

$\mathrm{N}=\{\mathrm{Z}$ 1- $\alpha$ sqrt*2P (1-P)] +Z 1- $\beta$ sqrt*P1 (1-P1) +p2 (1- p2) 2 / (p1-p2) 2

Where, $\mathrm{p}=$ mean of two proportion, $\mathrm{p} 1=$ Group $\mathrm{A}, \mathrm{p} 2=$ Group $\mathrm{B}$

\section{OBSERVATIONS AND RESULT}

\section{Effect of Therapy for Group A}

Pain

In assessment criteria of pain, in control group mean score before treatment was 3.00 and after treatment it was reduced to 0.96 . The pain score in lignocaine jelly got $68 \%$ relief occurs. P value is $<0.05$ means result is highly significant. Lignocaine jelly Stabilizes the neuronal membrane by inhibiting the ionic fluxes required for the initiation and conduction of impulses, thereby effecting local anaesthetic action. The onset of action is 3 to 5 minute.

\section{Spasm}

In this study, criteria of sphincter spasm in control group mean score before treatment it was 1.98 and after treatment it was reduced to 0.02 . P value is $<0.05$ means result is highly significant. $98 \%$ result was observed in criteria of sphincter spasm.

\section{Effect of Therapy for Group B}

Pain

In assessment criteria of pain, in experimental group mean score before treatment is 2.94 and after treatment 0.94 and P value is $<0.05$ means results is significant. Yashtimadhu Ghrita doesn't have any anaesthetic action but as per Ayurveda, reduces Vata (which was vitiated after the surgical procedure). It also included in Vedanasthapaka Gana i.e., reducing pain mentioned by Acharya Charaka.Yashtimadhu contains Glycyrrhizine and asparagine as active ingredients. Glycyrrhizine is a saponin widely used as an anti-inflammatory agent. Asparagine is a type of amino acid and act as analgesic (natural painkiller) and anti -inflammatory.

\section{Spasm}

In this study, secondary objectives were anal spasm. In criteria of spasm, mean score before treatment was 2.0 and after treatment it was reduced to 0.08 . P value is $<0.05$ means result is highly significant. $96 \%$ relief was occurred due to Gudapurana of Yashtimadhu Ghrita. Throughout digital examination maximum number of patients after treatment one finger easily admitted on 2nd day follow up. Sankocha i.e., spasm is one of the Karma of Vata and Yashtimadhu Ghrita pacify Vata and Ghrita reduces Pitta which ultimately causes relief in anal spasm.

Table 3: Showing comparison of pain and anal spasm in both groups in 100 post operative patients of Arsha (Hemorrhoids) and Parikartika (Fissure-in-ano)

\begin{tabular}{|c|c|c|c|c|c|c|}
\hline \multicolumn{2}{|c|}{$\begin{array}{c}\text { Subjective } \\
\text { Parameter }\end{array}$} & N & $\begin{array}{c}\text { Mean } \\
\text { Rank }\end{array}$ & $\begin{array}{c}\text { Sum of } \\
\text { Ranks }\end{array}$ & $\begin{array}{c}\text { Mann- } \\
\text { Whitney U }\end{array}$ & P - value \\
\hline \multirow{2}{*}{ Pain } & Group A & 50 & 51.42 & 2571.00 & & \\
\cline { 2 - 5 } & Group B & 50 & 49.58 & 2479.00 & \multirow{2}{*}{1204.000} & .599 \\
\cline { 2 - 5 } & Total & 100 & & & & \\
\hline \multirow{2}{*}{$\begin{array}{c}\text { Anal } \\
\text { Spasm }\end{array}$} & Group A & 50 & 50.50 & 2525.00 & & \multirow{2}{*}{1250.000} \\
\cline { 2 - 5 } & Group B & 50 & 50.50 & 2525.00 & & \\
\cline { 2 - 5 } & Total & 100 & & & & \\
\hline
\end{tabular}

For comparison between Group A and Group B, we have used Mann Whitney U Test. From above table we can observe that, P-Value the parameters are greater than 0.05 . Hence we conclude that, there is no significant difference observed in Group A and Group B. 


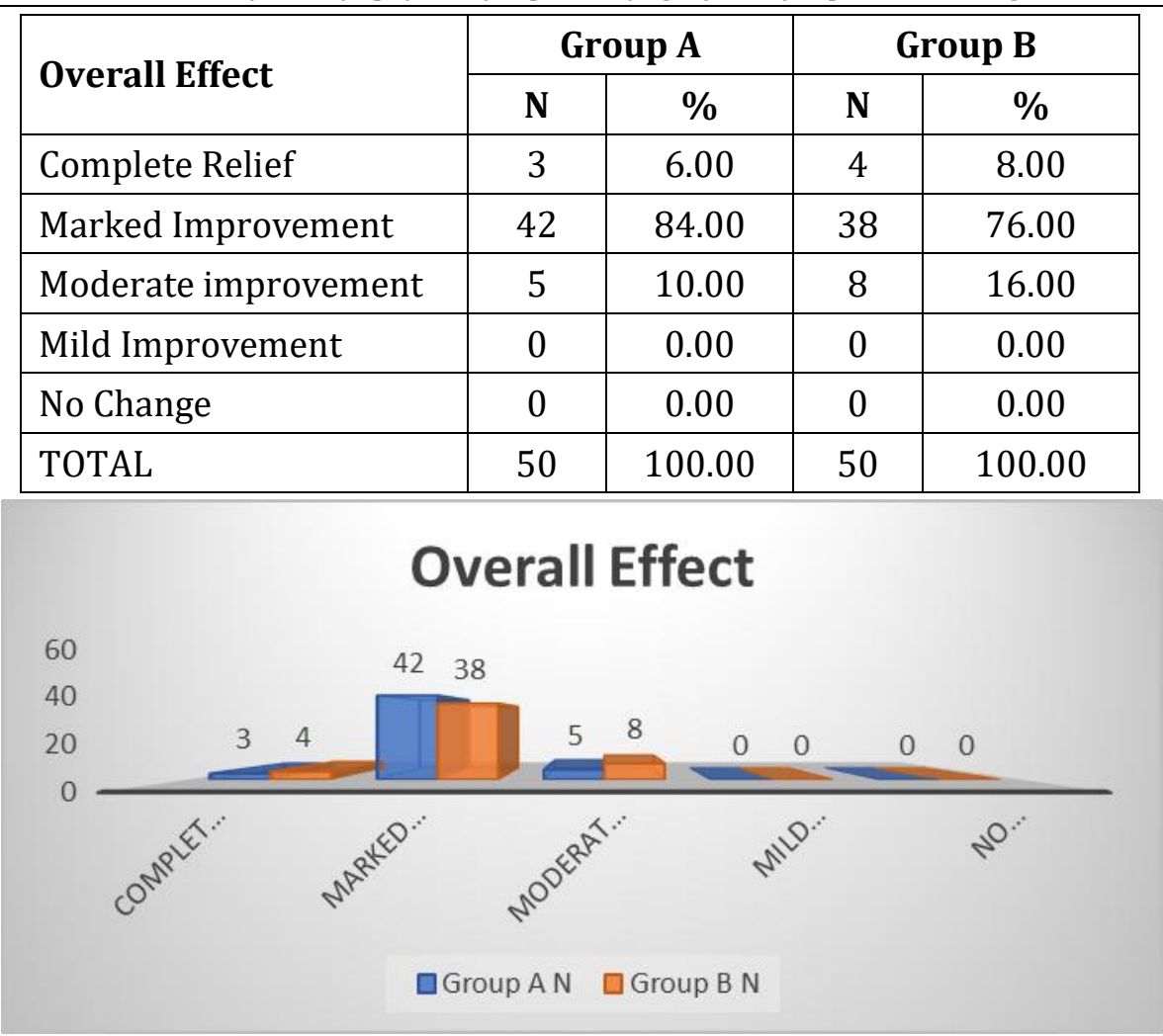

\section{DISCUSSION}

Yashtimadhu has Madhura Rasa, Madhura Vipaka, Sheet Virya and Vata Pittashamak property[8]. Yashtimadhu also has Vranaropana and Vrana Shodhana properties ${ }^{[9]}$. Go Ghrita has a soothing property and form thin film layer over them and then that allows early epithelization of skin. Yashtimadhu has proven healing, anti ulcerogenic, antiinflammatory and skin regeneration activity[10]. Sodium, glycyrrhizate possessed anti-ulcer activity and stimulation of regeneration of skin[11]. Yashtimadhu contains Glycyrrhizine and asparagine as active ingredients. Glycyrrhizine is a saponin widely used as an anti-inflammatory agent and Asparagine is a type of amino acid and act as analgesic (natural painkiller) and anti-inflammatory agent. Pain is stated to be also reduced due to Vednashamak effect of Yashtimadhu Ghrita local application without using. It doesn't only controls the pain but also act as Vatahara, Pitta Shamak, Ropaka, Dahashamak, Stambhak in Vrana ${ }^{[12],}$

\section{Previous study on Yashtimadhu ghrita also concluded as follows}

Jigna Ratilal Patel et al stated that Yashtimadhu ghrita as well as lignocaine- nifedipine ointment both are equally effective in symptomatic relief in the management of Parikartika (acute fissure in ano). In lignocaine -nidlfedipine ointment minor complications were noted[13],

Waghmare Dinesh et al concluded that most evident symptoms present i.e., pain and bleeding, burning sensation, itching can be relieved much earlier and fistula can heal much rapidly by the application of Yashtimadhu Ghrita rather than Tiktaadi Ghrita[14].

Dwivedi Amar prakash et al concluded that Symptoms present i.e., pain and bleeding, burning sensation, itching can be relieved much earlier and fissure can heal much rapidly by the application of Yashtimadhu Ghrita rather than Shatadhauta Ghrita[15].

Gadhari Anup Bhimrao et al stated that Yashtimadhu Ghrita with Madhu as a local application is clinically effective in post-operative haemorrhoidectomy patients. This treatment is devoid of any side effects. This treatment is devoid of side effects. This treatment can be used as supportive treatment modality for early recovery[16].

The previous work done with Yashtimadhu ghrita as trial drug are conclusive of its analgesic and wound healing properties. Also, Yashtimadhu Ghrita having various properties might be working on factors as pain and anal sphincter spasm and wound healing as well. Yashtimadhu Ghrita work as antiseptic and bactericidal on non-infected surgical wounds.

\section{CONCLUSION}

1. Yashtimadhu Ghrita as a local application is clinically as effective as lignocaine jelly in the management of post operative pain in patients of hemorrhoids and fissures in ano.

2. Reduction in the level of pain and anal spasm was equal when comparing effect of Yashtimadhu Ghrita with lignocaine jelly in post operative patients of hemorrhoides and fissure in ano. 
3. Overall both therapies are equally effective in the management of postoperative pain in the patients of hemorrhoids and fissures.

4. This treatment is devoid of any side effects.

\section{Future Scope of the Study}

1. Multicentric study can be carried out with large sample size.

2. In future, it can be used as an alternative option to modern topical application.

3. There is a scope for the study of Yashtimadhu Ghrita in combination with other Ayurvedic analgesic drugs for local application for post operative pain management

\section{REFERENCES}

1. Zephi Sun et al, Review of hemorrhoid disease: presentation \&management, Clinics in colon and rectal surgery, 2016: 29(1): 22-29.

2. Steele SR et al. Systematic review: the treatment of anal fissure, Alimentary pharmacology and therapeutics, 2006: (24): 246-257.

3. Narinder Rawal et al, Post-operative pain management after Haemorrhoidectomy, IASP (The International Association for the Study of Pain), 2013: 11(1): 1-5.

4. Shantha Mohan et al. Comparative study of manual Anal dilatation with fissurectomy versus lateral anal sphincterotomy in chronic fissure in ano, MEDPULSE, 2016: 3(2): 167-170.

5. Kaviraj Kunjalal Bhishagratna, sushruta samhita sutrasthan; chap 5/34, choukhamba Sanskrit series office, Varanasi, 19981, (1)42.

6. Dr.Anantram Sharma, Sushruta Samhita Sutrasthan; chap5/42, choukhamba surbharati prakashan, Varanasi, 2017, 1-44.

7. Nagindas Shah, Bharat Bhaishajya Ratnakar, drug no.5795(4), VTailprakaran 4, 302-303
8. Priyavat Sharma, Sushruta Samhita. Sutrasthan 5/42 choukhamba orientaliya publishers, Varanasi, 1993: 2:46.

9. Dr Dwivedi Amarprakash et al., A clinical study to evaluate the antiseptic and bactericidal effect of Yashtimadhu Ghrita in non-infected surgical wounds, IJAAR, 2015, 2(3).

10. Jigna Ratilal Patel et al. A comparative clinical study of Yashtimadhu Ghrita and lignocainenifedipine ointment in the management of Parikartika (acute fissure-in- ano), Department of Shalya Tantra, IPGT \& RA, Gujarat Ayurved University, Jamnagar, Gujarat, India, AYU, 2017: 38 (1-2): 46-51.

11. Dr.Ravindra Bhati. Role of yastimadhu ghrita pratisarana in management of oral cancer, WJPR, 2020: 9 (3) 352-360.

12. Waghmare Dinesh. A Comparative Study of Effect of Yashtimadhu Ghrita and Tikdadi Ghrita Locally in the Management of Post-Operative Fistulectomy Wound, IJAHM, 2016: 6(5) 2359-2365.

13. Jigna Ratilal Patel et al A comparative clinical study of Yashtimadhu Ghrita and lignocaine- nifedipine ointment in the management of Parikartika (acute fissure-in- ano), Department of Shalya Tantra, IPGT \& RA, Gujarat Ayurved University, Jamnagar, Gujarat, India, AYU, 2017: 38 (1-2): 46-51.

14. Waghmare Dinesh. A Comparative Study of Effect of Yashtimadhu Ghrita And Tikdadi Ghrita Locally in the Management of Post-Operative Fistulectomy Wound, IJAHM, 2016: 6(5): 2359-2365.

15. Dwivedi Amarprakash. A comparative study of effect of yashtimadhu ghrita and shatadhauta ghrita locally in the management of parikartika w.s.r. To acute fissure- in-ano IAMJ, 2016: 4(8) 2455-2462.

16. Gadhari Anup Bhimrao et al, Study of effect of Yashtimadhu Ghrita and Madhu local application in post-operative patients of haemorrhoidectomy IAMJ, 2014: 2(3) 677-682.

\section{Cite this article as:}

Yogesh Badwe, Sanjay Bhise, Jyoti Shinde. Effect of Yashtimadhu Ghrita Gudapurana on Post Operative Pain Management in Patients of Haemorrhoids and Fissure-inano with Special Reference to Shastranipataja Vedana: A Randomized Controlled Trial. International Journal of Ayurveda and Pharma Research. 2022;10(1):47-52. https://doi.org/10.47070/ijapr.v10i1.2246

Source of support: Nil, Conflict of interest: None Declared
*Address for correspondence Dr. Yogesh Badwe

Professor and HOD,

Department of Shalyatantra, Shri Ayurved Mahavidyalaya, Nagpur, Maharashtra, India. Email: dryogesh.badwe@gmail.com Mob: 9011060498

Disclaimer: IJAPR is solely owned by Mahadev Publications - dedicated to publish quality research, while every effort has been taken to verify the accuracy of the content published in our Journal. IJAPR cannot accept any responsibility or liability for the articles content which are published. The views expressed in articles by our contributing authors are not necessarily those of IJAPR editor or editorial board members. 